\title{
The Readiness of Arabic Language Teachers for Integrating Flipped Classroom: Case of Ma'an
}

\author{
Mustafa Jwaifell \\ Assoc. Prof., Instructional Technology, Faculty of Education, Al-Hussein Bin Talal \\ University, Jordan,jwaifell@hotmail.com \& jwaifell@ahu.edu.jo
}

Reema Abu-Omar

Asst. Prof., Al-Hussein Bin Talal University, Jordan, rema.r.amjad@gmail.com

Mohammad Al-Tarawneh

Prof, Al-Hussein Bin Talal University, Jordan, emt.lady@yahoo.com

\begin{abstract}
This paper investigates the readiness degree among Arabic language teachers in Ma'an Directorate of Education for integrating flipped classroom in teaching according to Technological, Pedagogical and Content Knowledge TPACK framework and its domains. The study sample consisted of (118) Arabic language teachers; (82) of them responded to a questionnaire that measured their readiness. The researchers used descriptive statistics, ANOVA and T-test. The data analyses revealed significant differences among teachers' readiness in a high degree. Two sample t-test showed female teachers' readiness higher than male teachers at the domains: CK, PK, PCK, TPK and TPCK. Results of ANOVA revealed that experience of teachers' readiness do not differ significantly. The study recommended the focus on integrating flipped classrooms within learning environments.
\end{abstract}

Keywords: flipped classroom, TPACK, Arabic Language, readiness, skills, standards, teachers training, Jordan

\section{INTRODUCTION}

While digital technologies invaded all fields of life including education, conduct, work and ways of living, based on smart phones and internet usage; teachers need to possess more competencies to integrate ICT in learning and teaching environments. To assure ICT competencies, integration with respect to curriculum components (e.g. aims, content, methodology and evaluation) and move away from technocentric approach to emphasize pedagogy and content, scholars suggested the technological pedagogical content knowledge (TPACK) framework (Mishra \& Koehler, 2006); 
Students already interact with those technologies in early age. This leads to a question about the use of technology in learning, and its role to play, beside teachers' acceptances and readiness. Tools of ICT came up with new pedagogical terms and e-learning types such as Flipped Classroom, in which sequence of learning situation is changed and reversed.

\section{The Role of Technology in Learning}

Teachers practice and design learning situations in a dynamic complexity environment (Leinhard \& Greeno, 1986; Spiro, Fletovich, Jacobson \& Coulson, 1991) to integrate the way students think and learn knowledge with the use of technologies. This approach imposed itself on learning environment as well as the educational policy makers' demands represented by the Ministry of Education in Jordan. Moreover, Queen Rania Teacher Academy, The Queen Rania Foundation for Education and Development and Queen Rania Center for Educational Technology and Information were founded to achieve the goal of training teachers on acquiring ICT competencies and practicing it within learning situations (Ministry of Education).

Technologies can present epistemology, which appears within the content as one of curriculum components, in different shapes transmitted into multimedia. Not to mention its effect on acquiring skills of reading, writing, listening and speaking, which can be acquired by an appropriate pedagogy practice in synchronous or asynchronous forms. Thus, teachers will have to change their pedagogical ways to be concentrated on students, and change their role into guiding and facilitating students' learning.

Flipped classroom can be considered as one of those modern innovations which can be practiced in a wide range without the need for using complex devises. In other words, students can use their own smart phones to navigate the Internet and engage themselves in learning activities assigned by their teachers.

\section{Flipped Classroom}

There is an increasing amount of literature about blending learning and face to face modalities (Garrison and Kanuka, 2004; Owston, York, and Murtha, 2013; Zacharis, 2015). Flipped Classroom as a blended learning strategy could be recognized mostly, when Salman Khan in 2004 began recording videos of his lessons. Flipped Classroom is an instructional strategy and a type of blended learning that reverses the traditional teaching and learning environment through delivering instructional content online. According to Bergmann, Overmyer \& Wilie (2015), Flipped Classroom is replacing direct instruction with videos and encouraging students to focus on important learning activities inside the classroom with their teachers. In short, it is a pedagogical model in which the typical lecture and homework elements of a course are reversed, so the teacher records his lecture for 10-20 minute video and students should take notes and write their questions while they are viewing it at home, after teaching them how to watch his recorded lectures. When the students return in the next day to their class, teacher and students engage in activities regarding their notes and questions and have instructions as they need. 


\section{Definition of Flipped Classroom}

Teaching and learning environment consist of teaching where it is the role of teachers and the procedures that they conduct to assess learning, while learning is the students' role throughout organized activities. In the form of flipped classrooms, the concept of flipped learning arose, where researchers considered both concepts reflecting or referring to a pedagogical practice that allow students to learn courses contents (epistemology) traditionally delivered in classroom lectures prior to class using technology including but limited to online videos. Students engage in active learning activities within class time and receive individually targeted feedback from instructors (Hamdan, McKnight, McKnight, \& Arfstrom, 2013).

The idea of a flipped classroom is a mindset, a methodology, not a mold that classrooms can be placed into (Brown, 2016). He defines flipped classroom as "a model of delivering instruction that shifts lectures from a class time activity to an at home activity and shifts "homework" from an at home activity to an in-class, critical thinking set of activities" (Brown, 2016. P.4). While Bergmann \& Sams (2012) defined the Flipped Classroom Model (FCM) as a blended learning model, which aims to facilitate teachers to make better use of the face-to-face sessions through minimizing teachers' lectures and increasing students' active learning and collaboration in learning activities.

In this research paper, researchers adopted the definition of Bishop \& Verleger (2013, P.5) and they define the flipped classroom as an "educational technique that consists of two parts: interactive group learning activities inside the classroom, and direct computer-based individual instruction outside the classroom".

\section{Instructional Design of Flipped Classroom}

The design principles for the flipped classroom are to provide students preliminary information before the class activity; encourage students to watch online lectures and prepare themselves before the class activity; organize assessment methods; link in-class activities with out-of-class activities; supply clear guidance; provide sufficient time for the completion of assignments; promote students to build a learning community; provide immediate feedback and the use of familiar technologies (Kim, Kim, Khera \& Getman, 2014).

Flipped classroom can be implemented in teaching languages as Ahmad (2016) suggested in her experiment on English Foreign Language (EFL) students. She stated that flipped classroom process can be done in three phases: planning, implementation, and evaluation. Planning phase consisted of two parts: content preparation and student orientation for stating objectives. Implementation phase, divides activities of flipping classroom into before, during and after class. Evaluation phase is concerned with students' projects before and after submission.

\section{Elements of Technological, Pedagogical, and Content Knowledge}

Scholars investigated Technological, Pedagogical, and Content Knowledge (TPACK) framework and analysed teachers' knowledge, readiness and perceptions in educational sciences (Cox \& Graham, 2009; Neiss et. al, 2009; Groth, Spickler, Bargner \& Bardzell, 2009; Koh, Tsai \& Tan, 2011; White \& Geer, 2013). TPACK consists of seven elements: 
Content Knowledge (CK): Teachers' knowledge of the subject matter they teach to their students, such as science, art, languages or history, this knowledge involves knowledge of epistemology levels (facts, concepts, roles, theories); Pedagogical Knowledge (PK): Teachers' knowledge of methodologies of teaching and learning; Technology Knowledge (TK): Knowledge of thinking about, and working with technology tools and resources including how to apply information; Pedagogical Content Knowledge (PCK): Transformation of the subject matter for teaching, where teachers adapt and tailor the instructional materials and media to alternative conceptions and students' prior knowledge, and it covers: teaching, learning, curriculum, assessment and reporting; Technological Content Knowledge (TCK): It is about how teachers' understanding of technology and their understanding of content influence one another; Technological Pedagogical Knowledge (TPK): The change of teaching and learning when particular technologies are used in particular ways, Technological Pedagogical Content Knowledge (TPCK): The meaningful and deeply skilled teaching with technology (Koehler \& Mishra, 2009).

\section{Related Studies}

There are no studies related to the flipped classroom concerning Arabic language, especially those measuring teachers' readiness for using flipped classroom. Most of the studies focused on science and learning English language. The available literature since (2014) includes five studies applied in the Arab countries:

Engin (2014) described a project that aimed to leverage the students' interest and experience of technology to develop their writing skills in English as a second language. The study was conducted in the United Arab Emirates, where the participants consisted of (18) female students aged 19-21. The researcher's main concern was extending flipped classroom model by developing second language writing skills through studentcreated digital videos. Results showed that there was tension between students as producers, and students as consumers; student-created videos promoted accuracy in English language learning.

Mireille (2014) investigated the impact of using flipped classroom instruction on the writing performance of twelfth grade female Emirates students and identified their perception of the flipped instruction in an ESL writing setting. The study revealed statistically significant differences between the mean scores in favour of the students who studied through flipped classroom.

Al-Harbi and Alshumaimeri (2016) examined the impact of applying the flipped classroom in teaching English grammar on secondary school students' performance, perception, and attitudes toward learning English independently. Findings of the study revealed that the flipped classroom strategy appeared to play a role in enhancing students' grammar performance; and their attitude toward using flipped classroom strategy in the EFL class was positive.

Alsowat (2016) investigated the effect of a suggested EFL flipped classroom teaching model on graduate students' English higher-order thinking skills, engagement and satisfaction. The study participants consisted of (67) graduated female students at Taif 
University. The study findings showed the importance of using flipped classroom in acquiring those skills.

The study of Ahmad (2016) aimed at investigating the effect of the flipped classroom on Egyptian EFL students' listening comprehension. Thirty-four 3rd-year EFL students at faculty of education, Suez University were involved in this study. The study concluded that the flipped classroom had a significant effect on listening comprehension of Egyptian EFL students.

Two studies (Bell, 2015; Prefume, 2015) conducted outside Arab countries, investigated using flipped classroom for the acquisition of language skills. Bell (2015) investigated student and teacher attitudes and beliefs about learning German in terms of traditional and flipped learning approaches. The data were collected by means of questionnaires which were completed at the beginning and end of the semester. Results indicated that students and teachers were overwhelmingly pleased with the results of students at the end of the semester based on the flipped classroom model. While Prefume (2015) explored the effectiveness and feasibility of a flipped classroom approach in a Japanese language classroom. A concurrent embedded strategy of mixed methods was utilized to study two sections of Japanese language courses at a university in Texas. The study found that both traditional lecture approach and flipped classroom approach were not differing from each other in acquisition Japanese language.

Studies related to TPACK frameworks as a measurement tool for readiness of using flipped classroom for learning languages were very little in literature. Piotrowski \& Witte (2016) examined how preservice English language arts teachers learn to teach by using technology. Their study stylized a case study approach to examine teachers' learning about flipped classroom and designing lessons integrating technologies in teaching. The researchers used TPACK framework to code all data gathered out of the nine participants. Findings showed that teachers learned from experience with technology tools. They could use these tools in their classrooms; they thought that flipped learning could potentially be helpful to secondary English teachers. They also believed that flipped learning could be used in a variety of lessons across the English curriculum, including writing instruction and literature study. Consistently they wanted to be confident in the content they were teaching when they flipped the instruction.

Previous studies such as (Ahmad (2016); Bell, 2015; Prefume, 2015 Alsowat (2016); Al-Harbi and Alshumaimeri (2016) used grades, test scores, and student course evaluations to determine the effectiveness of flipped learning. Only one previous study of Ahmad (2016) examined how pre-service teachers learn to flip instruction.

This study used the TPACK framework to investigate in-service teachers' readiness of using flipped classroom in teaching Arabic language which can be considered as a first study as far as the researchers' knowledge.

\section{Rational of the Study and Research Questions}

In this study, based on researchers' experiences in teaching hundreds of in-service teachers, graduated students (diploma, master and $\mathrm{PhD}$ ), Arabic language teachers still 
have barriers of using technologies in their practice. The typical methodologies were used in teaching Arabic Language. The force of policy makers and technologies itself, reveal the need of such readiness to use technologies. Arabic Language can be taught by using different types of e-learning, such as Web Quest (Abu-Taweleh, 2014) Social Networks Sites (SNS)SNS (Bazarah, 2016) and its effect on Arabic Language itself, where students use SNS heavily (Jwaifell, et. al, 2013; Al Doghmi, Al-Shalabi, Jwaifell, Andraws, Awajan \& Alrabea, 2013) in none academic usage, while Ahmad (2016) investigated the effect of the flipped classroom model on Egyptian EFL students' listening comprehension, but there still a shortage research of Arabic language teachers readiness of using flipped class rooms, therefore this study was conducted under the claim that Arabic language teachers in Ma'an Directorate have no prior knowledge about flipped classroom to find, thus readiness of flipped classroom usage. Therefore, this study is aimed at determining Ma'an Directorate Arabic language teachers' readiness for integrating Flipped Classroom, by answering the following questions:

1. What is the readiness degree of Arabic language teachers in Ma'an Directorate for integrating flipped classroom in teaching according to TPACK framework and its domains?

2. Do male and female Arabic language teachers in Ma'an Directorate differ in their readiness for integrating flipped classroom in teaching according to TPACK framework and its domains?

3. Do years of experience of Arabic language teachers in Ma'an Directorate have an effect on their readiness for integrating flipped classroom in teaching according to TPACK framework and its domains?

\section{METHOD}

The study adopted a descriptive research design. The researchers conducted a survey through using a measurement tool for collecting data on the readiness degree of Ma'an Directorate Arabic language teachers for integrating flipped classroom in teaching according to TPACK framework and its domains.

\section{The Study Population and Sample:}

The sample of this study consisted of all Arabic language teachers in Ma'an Directorate. All $(100 \%)$ population of the study is the sample itself (male $=49 /$ female $=69)$. Only $(82)$ of the questionnaires were returned or were valid to be analysed, as shown in Table 1:

Table 1

The study population and its sample

\begin{tabular}{lllllll}
\hline \multirow{2}{*}{$\begin{array}{l}\text { Years of } \\
\text { Experience }\end{array}$} & Gender & \multicolumn{3}{l}{ Total } & \\
\cline { 2 - 6 } & Male & Female & & \\
\cline { 2 - 6 } & Population & Sample & Population & Sample & Population & Sample \\
\hline $1-5$ & 24 & 16 & 23 & 16 & 47 & 32 \\
\hline $6-10$ & 26 & 19 & 15 & 7 & 41 & 26 \\
\hline More than 10 & 19 & 15 & 11 & 9 & 30 & 24 \\
\hline Totals & 69 & 50 & 49 & 32 & 118 & 82 \\
\hline
\end{tabular}


The researchers' main concern was to measure the readiness degree of Ma'an Directorate Arabic language teachers for integrating flipped classroom in teaching according to TPACK framework and its domains in order to understand the whole picture of their aptitudes and give recommendations to the administration of Ministry of Education in Jordan, and universities for better understanding when planning for teachers' training and pre-service training. All the teachers in the study have Bachelor's degree and none of them hold a diploma.

\section{The Measurement Tool}

The study developed and modified the TPACK framework used by (Almalaheem, 2016) as a measurement tool for measuring the readiness degree of Ma'an Directorate Arabic language teachers for integrating flipped classroom in teaching. When analysing the items content, it appeared to the researchers and the 6 referees that those items did not have any cultural biases and commonly applicable to the Ma'an directorate teachers in Jordan as within Middle Eastern context. The Arabic version was validated by 6 referees of Al-Hussein Bin Talal University instructors who hold $\mathrm{PhD}$ degrees in Instructional Technology, Information Technology, Curriculum and Instruction, Education Foundation and Statistics. The reliability of the questionnaire was calculated using Cronbach's Alpha Coefficient, as shown in Table 2:

Table 2

Reliability of TPACK domains

\begin{tabular}{llll}
\hline Domain & $\begin{array}{l}\text { N of } \\
\text { items }\end{array}$ & $\begin{array}{l}\text { Cronbach's } \\
\text { Alpha }\end{array}$ & $\begin{array}{l}\text { Pearson } \\
\text { correlation }\end{array}$ \\
\hline Technological Knowledge (TK) & 10 & 0.805 & $0.800^{* *}$ \\
\hline Content Knowledge (CK) & 8 & 0.785 & $0.660^{* *}$ \\
\hline Pedagogical Knowledge (PK) & 11 & 0.803 & $0.676^{* *}$ \\
\hline Pedagogical Content Knowledge (PCK) & 5 & 0.720 & $0.578^{* *}$ \\
\hline Technological Content Knowledge (TCK) & 6 & 0.850 & $0.846^{* *}$ \\
\hline Technological Pedagogical Knowledge (TPK) & 11 & 0.895 & $0.854^{* *}$ \\
\hline Technological Pedagogical Content Knowledge (TPCK) & 7 & 0.829 & $0.715^{* *}$ \\
\hline Total of Readiness & 58 & 0.945 & \\
\hline
\end{tabular}

** Correlation is significant at the 0.01 level (2-tailed)

Measurement scale of the tool was transformed into five levels of readiness as shown in table 3:

Table 3

Scaling readiness levels

\begin{tabular}{lllll}
\hline Strongly don't agree & Don't agree & Neutral & Agree & Strongly agree \\
\hline 1 & 2 & 3 & 4 & 5 \\
\hline $1-1.80$ & $1.81-2.60$ & $2.61-3.40$ & $3.41-4.20$ & $4.21-5$ \\
\hline Very week readiness & $\begin{array}{l}\text { Week } \\
\text { readiness }\end{array}$ & $\begin{array}{l}\text { Medium } \\
\text { readiness }\end{array}$ & High readiness & Very high readiness \\
\hline
\end{tabular}




\section{The Study Context}

To answer the study questions, teachers participated in a brief workshop and read a brochure illustrating flipped classroom concept, design, webhosts and usage in teaching and learning situations regarding Arabic language. The brochure was distributed along with the measurement tool (TPACK). Teachers were given three weeks to feel free to communicate with each other and use flipped classroom before applying the measurement tool (TPACK) for collecting data about their readiness for integrating flipped classroom.

\section{Data Analysis}

The gathered ratio data classified and analysed to answer the study question. Hence the classified variables have on, two or three levels, different types of statistical procedures were used: One sample t-test was used to answer the first question, for the second question two-sample t-test, while One-way ANOVA and Scheffe's multiple comparison test.

\section{FINDINGS AND DISCUSSION}

The Analyses of the resulting ratio data were performed using descriptive statistics. Descriptive measures including means and standard deviations for TPACK domains were calculated to answer the questions of the study. These descriptive statistical measures were also tabulated and reported for classifying the variables (gender and years of experience) to determine the teachers' readiness for integrating flipped classroom according to TPACK framework. Results according to questions of the study were as follow:

Results of Q1: What is the readiness degree of Arabic language teachers in Ma'an Directorate for integrating Flipped Classroom in teaching according to TPACK framework and its domains?

The analyses of One sample t-test with $(\mathrm{df}=81)$ where used to determine the teacher's readiness at the crucial score of upper bound of readiness degree (see table 3 ):

Table 4

Results of One sample t-test

\begin{tabular}{|c|c|c|c|c|c|c|}
\hline Domains & Mean & SD & Readiness Degree & Crucial Score & T value & Sig \\
\hline TK & 3.60 & 0.57 & \multirow{2}{*}{ High } & \multirow{2}{*}{3.40} & 3.249 & .002 \\
\hline CK & 4.16 & 0.46 & & & 14.897 & .000 \\
\hline PK & 4.25 & 0.40 & Very High & 4.20 & 1.165 & .247 \\
\hline PCK & 3.96 & 0.59 & \multirow[t]{5}{*}{ High } & \multirow[t]{5}{*}{3.40} & 8.647 & .000 \\
\hline TCK & 3.75 & 0.68 & & & 4.691 & .000 \\
\hline TPK & 3.73 & 0.60 & & & 4.979 & .000 \\
\hline TPCK & 3.71 & 0.63 & & & 4.477 & .000 \\
\hline Readiness & 3.89 & 0.41 & & & 10.686 & .000 \\
\hline
\end{tabular}

One sample t-test revealed that there aren't significant differences at $\alpha \leq 0.05$ between the mean of PK (4.16) and the crucial score (4.20) which represents the upper bound of 
High degree. While there are significant differences between the means of (TK, CK, PCK, TCK, TPK and Readiness) and the crucial score (3.40) which represents the upper bound of High degree. Thus, the readiness degree of Ma'an Directorate Arabic language teachers for integrating Flipped Classroom in teaching according to TPACK framework and its domains is a high degree.

Those findings show that Arabic teachers have high competencies when they have the opportunity to explore different approaches on the basis of technologies, as the highest readiness degrees were in both content and pedagogical knowledge, which can be attributed to their competencies which have been developed by workshops in which they participated. Still there is a lack of technological knowledge when comparing its mean with CK, PC, PCK, TCK, TPK and TPCK, but still it is at a high degree.

Based on these results, it appears that the teachers' readiness is very high, but teachers have 24 classes every week, which is considered a very high load and they are restricted to a low range of pedagogies that are supervised by the administration. On the other hand, not all parents have an open mind for new methodologies of learning and teaching nor all of them can afford smart phones to their children. The Ministry of Education in Jordan is working within a very humble budget to reform and organize curriculum based on this kind of technology and pedagogical methodologies.

Results of Q2: Do male and female Arabic language teachers in Ma'an Directorate differ in their readiness for integrating Flipped Classroom in teaching according to TPACK framework and its domains?

The analyses of two sample t-test with $(\mathrm{df}=80)$ where used to determine the male/female teacher's differences in their readiness for integrating Flipped Classroom in teaching according to TPACK framework and its domains as shown in Table 5:

Table 5

Results of two sample t-test

\begin{tabular}{|c|c|c|c|c|c|c|}
\hline \multirow[t]{2}{*}{ Domains } & \multicolumn{2}{|c|}{ Male. $\mathrm{N}=32$} & \multicolumn{2}{|c|}{ Female. $\mathrm{N}=50$} & \multirow[t]{2}{*}{$\mathrm{T}$ value } & \multirow[t]{2}{*}{ Sig } \\
\hline & Mean & $\mathrm{SD}$ & Mean & $\mathrm{SD}$ & & \\
\hline TK & 3.42 & 0.63 & 3.72 & 0.50 & 2.388 & .019 \\
\hline CK & 4.12 & 0.46 & 4.19 & 0.47 & 0.609 & .544 \\
\hline $\mathrm{PK}$ & 4.24 & 0.39 & 4.26 & 0.41 & 0.132 & .896 \\
\hline PCK & 3.88 & 0.47 & 4.02 & 0.65 & 1.061 & .292 \\
\hline TCK & 3.47 & 0.74 & 3.93 & 0.58 & 3.186 & .002 \\
\hline TPK & 3.60 & 0.52 & 3.81 & 0.64 & 1.587 & .116 \\
\hline TPCK & 3.69 & 0.66 & 3.72 & 0.61 & 0.197 & .844 \\
\hline Readiness & 3.78 & 0.42 & 3.95 & 0.40 & 1.814 & .073 \\
\hline
\end{tabular}

Two sample t-test revealed no significant differences at $\alpha \leq 0.05$ between the means of male/female at the domains (CK, PK, PCK, TPK, TPCK and Readiness). While there are significant differences between the means of male/female in both of the domains TK and TCK. Thus, male and female Arabic language teachers in Ma'an Directorate do not differ in their readiness for integrating Flipped Classroom in teaching according to TPACK framework and its domains, except for the TK and TCK domains. 
Results of Q3: Do years of experience of Arabic language teachers in Ma'an Directorate have an effect on their readiness for integrating Flipped Classroom in teaching according to TPACK framework and its domains?

To answer the third question, means and standard deviations were calculated to examine the differences of readiness according to years of experience as shown in Table 6:

Table 6

Means and standard deviations according to years of experience

\begin{tabular}{lllllll}
\hline Domains & \multicolumn{2}{l}{$1-5$ years. N=32 } & \multicolumn{2}{l}{$6-10$ years. $\mathrm{N}=26$} & \multicolumn{2}{l}{ 11 years and more. $\mathrm{N}=24$} \\
\cline { 2 - 7 } & Mean & SD & Mean & SD & Mean & SD \\
\hline TK & 3.44 & 0.58 & 3.65 & 0.59 & 3.78 & 0.49 \\
\hline CK & 3.98 & 0.44 & 4.27 & 0.44 & 4.28 & 0.46 \\
\hline PK & 4.11 & 0.41 & 4.27 & 0.37 & 4.42 & 0.36 \\
\hline PCK & 3.88 & 0.57 & 4.00 & 0.68 & 4.03 & 0.51 \\
\hline TCK & 3.65 & 0.73 & 3.84 & 0.65 & 3.79 & 0.65 \\
\hline TPK & 3.65 & 0.62 & 3.93 & 0.53 & 3.62 & 0.61 \\
\hline TPCK & 3.58 & 0.67 & 3.82 & 0.56 & 3.76 & 0.62 \\
\hline Readiness & 3.76 & 0.42 & 3.98 & 0.42 & 3.96 & 0.36 \\
\hline
\end{tabular}

Table 6 shows significant differences between the means of readiness for integrating Flipped Classroom in teaching according to years of experience. One-way ANOVA was conducted to examine the significant differences as shown in Table 7:

Table 7

One-way ANOVA summery

\begin{tabular}{lllllll}
\hline Source of Variance & Sum of Squares & df & Mean Square & F & Sig. \\
\hline TK & Between Groups & 1.653 & 2 & 0.827 & 2.637 & .078 \\
\cline { 2 - 7 } & Within Groups & 24.765 & 79 & 0.313 & & \\
\hline CK & Between Groups & 1.694 & 2 & 0.847 & 4.292 & .017 \\
\cline { 2 - 7 } & Within Groups & 15.595 & 79 & .197 & & \\
\hline PK & Between Groups & 1.300 & 2 & 0.650 & 4.365 & .016 \\
\cline { 2 - 7 } & Within Groups & 11.763 & 79 & 0.149 & & \\
\hline PCK & Between Groups & 0.402 & 2 & 0.201 & 0.576 & .564 \\
\cline { 2 - 7 } & Within Groups & 27.553 & 79 & 0.349 & & \\
\hline TCK & Between Groups & 0.564 & 2 & 0.282 & 0.605 & .549 \\
\cline { 2 - 7 } & Within Groups & 36.838 & 79 & 0.466 & & \\
\hline TPK & Between Groups & 1.541 & 2 & 0.771 & 2.210 & .116 \\
\cline { 2 - 7 } & Within Groups & 27.549 & 79 & 0.349 & & \\
\hline TPCK & Between Groups & 0.910 & 2 & 0.455 & 1.169 & .316 \\
\cline { 2 - 7 } & Within Groups & 30.741 & 79 & 0.389 & & \\
\hline Readiness & Between Groups & 0.881 & 2 & 0.440 & 2.702 & .073 \\
\cline { 2 - 7 } & Within Groups & 12.871 & 79 & 0.163 & & \\
\hline
\end{tabular}


Results of the ANOVA revealed no significant differences at $\alpha \leq 0.05$ between the means of years of experience at the domains (TK, PCK, TCK TPK, TPCK and Readiness), While there are significant differences between the means of years of experience categories in both CK and PK domains. Thus, Arabic language teachers in Ma'an Directorate do not differ in their readiness for integrating Flipped Classroom in teaching according to TPACK framework and its domains based on their years of experience, except for CK and PK domains. Scheffe's Post multiple comparison was conducted to assure those differences as shown in Table 8:

Table 8

Results of Scheffe's Multiple Comparison

\begin{tabular}{|c|c|c|c|c|c|}
\hline $\begin{array}{l}\text { Dependent } \\
\text { Variable }\end{array}$ & (I) Experience & (J) Experience & $\begin{array}{l}\text { Mean Difference } \\
(\mathrm{I}-\mathrm{J})\end{array}$ & Std. Error & Sig. \\
\hline \multirow[t]{2}{*}{ CK } & From 1-5 & From 6-10 & -.28876 & .11731 & .054 \\
\hline & & from 11 and more & $-.30078(*)$ & .11998 & .049 \\
\hline \multirow[t]{2}{*}{ PK } & From 1-5 & From 6-10 & -.16193 & .10188 & .288 \\
\hline & & from 11 and more & $-.30587(*)$ & .10420 & .017 \\
\hline
\end{tabular}

* The mean difference is significant at the .05 level.

Post comparisons showed that teachers with 11 years of experience and more with the mean (CK Mean=4.28 and PK Mean=4.42) have higher readiness degree for integrating Flipped Classroom in teaching than teachers with (1-5) years of experience with the mean (CK Mean=3.98 and PK Mean=4.11). This result can be referred to the Ministry of Education in Jordan to promote the training of in-service teachers by giving them more opportunities to involve in more workshops on educational technology.

Findings of the study are very consistent with the findings of related studies. This study revealed the high degree of teachers' readiness for using flipped classroom, which reflects their positive perceptions of using it. Al-Harbi and Alshumaimary's study (2016) indicated a similar finding revealing that students' attitudes changed positively when they learned by flipped classroom. However, the two studies differ with regard to the sample and methodology used.

Mireille's study (2014) showed that students' perception of the flipped instruction changed when they used the proposed model, they have considered it more efficient. Efficiency can lead to high perception as the study finding showed.

Overall, findings of related studies about flipped classroom showed its importance and how it can change attitudes toward using it as an effective instructional strategy in education. Also the study findings reflected a sense of consistency between teachers' readiness and their acceptance of using flipped classroom.

\section{CONCLUSION}

This study revealed the readiness of Arabic language teachers' to integrate flipped classroom in teaching. These findings have implications for efforts to use flipped classroom as an effective type of e-learning. The results of this descriptive study help to 
clarify the aptitude of Arabic teachers to use e-learning types, especially Flipped Classroom. There have to be more workshops to overcome the lack of skills in some of TPACK domains. Policy makers can take advantages of technology and integrating them into learning situations.

\section{REFERENCES}

Abu Taweleh, Saleh. (2014). The Effect Of Using Web Quest On The Arabic Language's Cognitive Achievement Of 9th Grade Students In Jordan. (Unpublished master's thesis)., Al Hussein Bin Talal University. Jordan.

Ahmad, Samah. (2016). The Flipped Classroom Model to Develop Egyptian EFL Students' Listening Comprehension. English Language Teaching, 9(9), 166-178.

Al Doghmi, A., Al-Shalabi, H., Jwaifell,M. , Andraws, S., Awajan, A., \& Alrabea, A. I.(2013).The academic use of social networks among university students in Jordan. International Journal of Computer Science Issues, 10(5), 134-141.

Al-Harbi, Sarah \& Alshumaimeri, Yousif. (2016) The flipped classroom impact in grammar class on EFL Saudi secondary school students' performance and attitudes. English Language Teaching; Vol. 9, No. 10, 60-80.

Alsowat, Hamad. (2016). An EFL Flipped Classroom Teaching Model: Effects on English Language Higher-order Thinking Skills, Student Engagement and Satisfaction. Journal Education and Practice. Vol. 7, No. 9, 108-121

Bazarah, Mariam. (2015). The Relationship between Social Network Sites and Arabic Language Skills Acquisition among Secondary Stage Female Students from Arabic Language Teachers Point View Researcher. (Unpublished master's thesis)., Creative Sciences University. UAE.

Bell, T. R. (2015). The flipped German classroom. Proceeding of The Central states Conference in the Teaching of Foreign Languages Report (pp. 17-38).

Bergmann, J., Overmyer, J., \& Wilie, B. (2015). The Flipped Class: Myths vs. Reality THE DAILY RIFF - Be Smarter. About Education. Thedailyriff.com. Retrieved 5 January 2017, from: http://www.thedailyriff.com/articles/the-flipped-class-conversation689.php

Bergmann, J., and Sams, A., (2012). Flip your classroom: Reach every student in every class every day. International Society for Technology in Education, Washington, USA.

Bishop, J.L. \& Verleger, M.A. (2013) "The Flipped Classroom: A Survey of the Research," 120th American Society of Engineering Education Annual Conference \& Exposition, Atlanta, Georgia, United States, June 23-26.

Brown, Becki A., "Understanding the Flipped Classroom: Types, Uses and Reactions to a Modern and Evolving Pedagogy" (2016). Culminating Projects in Teacher Development. Paper 12. 
Chai, C., Koh, J., Tsai, C., \& Tan, L. (2011). Modeling primary school pre-service teachers' Technological Pedagogical ContentKnowledge (TPACK) for meaningful learning with information and communication technology (ICT). Computers \& Education. 57(1), 1184-1193.

Cox, S., \& Graham, C. R. (2009). Diagramming TPACK in practice: Using an elaborated model of the TPACK framework to analyze and depict teacher knowledge. TechTrends: Linking Research \& Practice to Improve Learning, 53(5), 60-69. doi:10.1007/s11528-009-0327-1.

Engin, Marion. (2014). Extending the flipped classroom model: Developing second language writing skills through student-created digital videos. Journal of the Scholarship of Teaching and Learning, Vol. 14, No. 5, December 2014, pp. 12 - 26. doi: 10.14434/josotlv14i5.12829.

Garrison, D. R., \& Kanuka, H. (2004). Blended learning: Uncovering its transformative potential in higher education. The Internet and Higher Education, 7(2), 95-105. http://doi.org/10.1016/j.iheduc.2004.02.001

Groth, R., Spickler, D., Bergner, J., \& Bardzell, M. (2009). A qualitative approach to assessing technological pedagogical content knowledge. Contemporary Issues in Technology and Teacher Education (CITE Journal), 9(4), 392-411.

Hamdan, N., McKnight, P., McKnight, K., \& Afstrom, K. M. (2013). A review of flipped learning. Retrive from Flipped Learning Network website: http://www.flippedlearning.org/review

Jwaifell, M., Al-Shalabi, H., Andraws, S., Awajan, A., \& Alrabea, A. (2013). The intensity of social networks group use among the students of Jordanian universities. Global Journal of Computer Science and Technology Network, Web \& Security, 13(2), 1-8.

Kim, M., Kim, S., Khera, O., \& Getman, J. (2014). The experience of three flipped classrooms in an urban university: an exploration of design principles. The Internet and Higher Education, 22, 37-50.

Koehler, M. J., and Mishra, P. (2009). What is technological Pedagogical content knowledge? contemporary Issues in Technology and teacher Education, 9(1). Pp. 6070 .

Misiry of Educaion. Queen Rania Center for Education and Information Technolog. Vission and Mission. Available at: http://www.moe.gov.jo/en/node/18777

Mireille, Farah. (2014). The Impact of Using Flipped Classroom Instruction on the Writing Performance of Twelfth Grade Female Emirates Students in the Applied Technology High School (ATHs). Unpublished theses. The British University in Dubai. United Arab Emirates. Available at: https://bspace.buid.ac.ae/bitstream/1234/676/1/120088.pdf 
Mishra, P., \& Koehler, M. J. (2006). Technological pedagogical ConTenT Knowledg: A Framework for Teacher knowledge. Teachers college Records, 108(6), 1017-1054.

Muir, T., \& Chick, H. (2014). Flipping the classroom: A case study of a mathematics methods class. In J. Anderson, M. Cavanagh, \& A. Prescott (Eds.). Curriculum in focus: Research guided practice (Proceedings of the 37th annual conference of the Mathematics Education Research Group of Australasia, pp. 485-492). Sydney: MERGA.

Lienhard, G, \& Greeno, J. (1986). The cognitive skills of teaching. Journal of Educational Psychology, 78(2), 75-95.

Niess, M. L., Ronau, R. N., Shafer, K. G., Driskell, S. O., Harper S. R., Johnston, C., Browning, C.,Özgün-Koca, S. A., \& Kersaint, G. (2009). Mathematics teacher TPACK standards and development model. Contemporary Issues in Technology and Teacher Education, 9(1), 4-24.

Owston, R., York, D., \& Murtha, S. (2013). Student perceptions and achievement in a university blended learning strategic initiative. The Internet and Higher Education, 18, 38-46. http://doi.org/10.1016/j.iheduc.2012.12.003.

Piotrowski, A., \& Witte. S. (2016). Flipped Learning and TPACK construction in English education. International Journal of Technology in Teaching and Learning, 12(1), 33-46

Prefune, Yuko. (2015). Exploring a Flipped Classroom Approach in a Japanese Language Classroom: a Mixed Methods Study. Unpublished Dissertaion. Baylor University. Available at: https://baylor-ir.tdl.org/baylorir/bitstream/handle/2104/9569/PREFUME-DISSERTATION-2015.pdf?sequence=1

Shaffer Shelly. (2015). One High School English Teacher: On His Way to a Flipped Classroom. Journal of Adolescent \& Adult Literacy, 59(5), 563-573. doi: 10.1002/jaal.473

Spiro, R, J., Feltovich, P, J., J, \& Coulson, R, L. (1991). Knowledge representation, content specification, and the development of skill in situation-knowledge assembly: some constructivist issues as they relate to cognitive flexibility theory and hyper text, Educational technology, 31(9), 22-25.

Swidan, A., Al-Shalabi, H., Jwaifell, M., Awajan, A., \& Alrabea, A. (2013). The intensity and the factors affecting the use of social network sites among the students of Jordanian universities. International Journal of Computer Science Issues, 10(1), 492498.

White, Bruce, \& Geer, Ruth. (2013). Preservice teachers experience with online modules about PACK. Australian Educational Computing, 27(3), 124-132.

Zacharis, N. Z. (2015). A multivariate approach to predicting student outcomes in webenabled blended learning courses. The Internet and Higher Education, 27, 44-53. http://doi.org/10.1016/j.iheduc.2015.05.002 